\title{
Ahogyan tanulni fogunk
}

A szerző provokatív hangvételü, vitára ingerlő cikkében nem kevesebbet állít, mint hogy a piaci és a politikai erők új egyetemi struktúra létrejöttét sürgetik. Az adat, az információ és a tudás fogalmát elemezve megállapítja, hogy az adat valamilyen eszközzel létrehozott szimbólum, za információ nem más, mint valaki számára többletjelentéssel bíró adat, a tudás pedig a megfelelő cselekvésre való képesség. Az egyetemi oktatást- Lewis Perelman nyománvendéglőhöz hasonlítja, ahol az étlapon levő szimbólumok az adatok, az étterem kínálatának megértése az információ, a tudás pedig maga az étkezés. A legtöbb tanterv azon a feltevésen alapszik, hogy információ-értékű adatok halmazát kell a hallgatókhoz eljuttatni, az egyetemek tehát többnyire csak az étlapig jutnak el, holott „nem a tintát szoktuk lenyalogatni vagy esetleg magát az étlapot megenni ... segélykiáltásunk a kompetenciáért vacsora hiányában nem más, mint éhségérzetünk kifejezése”. Az egyetemi oktatás az új igények alapján át fog alakulni, egyrészt a hallgatók elvárásai szerint, akik a tanulásba való befektetésük megtérülését várják, másrészt az üzleti szféra gyakorlati szaktudási követelményei szerint. A hallgatókért folytatott küzdelemben új versenytársak tűnnek fel. A tanulás forradalmában a digitális média és az internet segítségével a hagyományos lineáris tanulás helyett sokdimenziós „hiper-tanulási környezet” fog alakulni.

\section{Szerzői információ:}

Peter J. Denning

Jelenleg a Naval Posztgraduális Intézetben a Számítástudományi Tanszék vezetôje, valamint a Cebrowski Intézet igazgatója a kaliforniai Monterey-ben. Korábban ő irányította az iowai Amesban a Számítástudományok Fejlesztéséért Kutatóintézet létrehozását a NASA Kutatási Központjában, továbbá részt vett a CSNET megalapításában is.

Nevéhez füzôdik az úgynevezett ,working set" modell kifejlesztése, közremûködött az operáció-analízis kimunkálásában, és hozzájárult ahhoz is, hogy a virtuális memória az operációs rendszerek állandó részévé váljon. A számítógépekkel, a hálózatokkal és az operációs rendszerekkel kapcsolatban már 7 könyv és 290 cikk szerzőjeként ismerhetjük. Oktatói, kutatói és szerzối munkásságát számos rangos díjjal elismerték.

Így hivatkozzon erre a cikkre:

Denning, Peter J.. „Ahogyan tanulni fogunk”.

Információs Társadalom III, 2. szám (2003): 128-146.

$\Longrightarrow$ https://dx.doi.org/10.22503/inftars.III.2003.2.9


Szerkesztöségünk Peter J. Denning vitára késztető esszéjével kapcsolatban várja minden kedves olvasó véleményét, hozzászólását az inftarsfolyoirat@ittk.hu email címre. A beérkezett irások közül a legérdekesebbeket a folyóirat következó számában közöljük.

A szerk.

Peter J. Denning

\section{Ahogyan tanulni fogunk}

A XX. század végével a felsőoktatásra egyre több nyomás nehezedik. Olyan erôpróbáló, olykor egymással nehezen összeegyeztethetô kihívásokkal kell szembenéznünk, amelyek alapjaiban fogják megváltoztatni a felsőoktatás feladatkörét, fóleg az oktatás és a kutatás terén. Ahhoz, hogy az oktatási oldalon megszűnjenek a feszültségek, különbséget kell tenni a „tudás” és az „információ” fogalma, a „tudni hogyan” és a „tudni róla” között.

A továbbtanulási lehetőségek az aktív szakemberek igényeihez és érdekeihez fognak igazodni, előtérbe kerül az egyes foglalkozási területeken szükséges szakirányú tudás. A fent említett különbségtétel újabb kötelezettséget ró a felsőoktatásra: széleskörű rálátásra van szükség ahhoz, hogy meg tudjunk birkózni a világot jellemzố komplexitással és bizonytalansággal; hogy vállalkozó szellemûek legyünk, de bölcsen tudjunk cselekedni és szoros társadalmi kapcsolatokat tudjunk kiépíteni

A digitális média és az internetes kommunikációs eszközök révén a tanulási folyamat a hagyományos, lineáris környezetből egy új, nem-lineáris, „hiper” tanulási környezetbe helyezôdik át. Ez pedig egy új tanártípus megjelenését is maga után vonja: az olyan oktatók megjelenését, akik nem csupán információt adnak át, hanem inkább irányítják hallgatóikat és felkészítik ôket az életre.

Az egyetemekkel versengve privát, profitorientált szerveződések fognak oktatási szolgáltatásokat kínálni, főleg közvetítôként, de tartalomszolgáltatóként is. Azok az egyetemek, amelyek nem tudnak ehhez alkalmazkodni, meg fognak szúnni. A kutatások területén társadalmi szerződés jön létre az egyetemek, az üzleti szektor és a kormányzati szektor között. Az egyetemi kutatás szerepköre is bővülni fog. Két jelentôs változás fog történni: egyrészt alkalmazott kutatási partnerkapcsolat jön létre az egyetemek és a vállalatok között; másrészt közös érdek lesz, hogy a hatékonyabb tanulással és információ-kiválasztással kapcsolatban is végezzenek kutatásokat. A kutatások nem maradnak majd félbe támogatás hiányában, hiszen az egyetemek eléggé vállalkozó szelleműek lesznek ahhoz, hogy szponzorokat találjanak. Az új érdekkapcsolatokra a szabadságérzet és a vállalkozókedv lesz jellemző, s a felsôoktatás a reneszánszát fogja élni. Ez a szellemiség végül elterjed a középiskolák szintjén is. 


\section{Ellenállhatatlan erők és elmozdíthatatlan akadályok}

A XX. század vége az oktatás egyik legvirágzóbb és egyben legválságosabb korszaka is. Az emberek - jobban, mint valaha - bíznak az oktatásban, s azt remélik, hogy segítségével legyốzik a szegénységet, jó álláshoz jutnak, karrierlehetôségeik javulnak, vagyis értelmes és teljes életet tudnak élni. Ugyanakkor egyre nagyobb igényeket támasztanak az oktatással szemben, fogyasztói elvárásaik megnőnek. Azt szeretnék, ha az egyetemi képzés a tudás minden ágazatára kiterjedne, a művészetektől a tárgyi kultúra történetéig. Ezen kívül több konzultációs lehetôséget és tanári segítséget, kisebb csoportlétszámokat és kevesebb bürokráciát akarnak. Széleskörű oktatást és alacsonyabb költségeket szeretnének. Végül több biztosítékot kívánnak arra, hogy a végzôsök megfelelố gyakorlati tudással hagyják el az egyetemet, és hamar álláshoz jussanak.

Ez a visszás helyzet az információ- és kommunikációs technológia (IKT) robbanásszerú elterjedése miatt alakult ki. Az IKT nemcsak a munkahelyi és társasági szokásokat változtatja meg, hanem az embereknek az oktatással szemben támasztott igényeit és az oktatásba vetett hitét is. A világon jelenleg hetenként több mint egy milliárd mikrochipet gyártanak és építenek be a legkülönbözóbb termékekbe. A mikrochip mindenütt jelen van és máris olyan új piacokat teremtett, amelyekrôl 1990-ben még álmodni sem mertünk. A piaci és politikai csoportosulások új korszaka nyílik meg. A mikrochip - a CD-ROM-ok, a kábeltelevízió, a modemek és az Internet közvetítésével - nagy kihívást jelent a könyv, a könyvtár és az osztályterem számára, hiszen az ismeretekhez való hozzáférés újszerû lehetôségei révén még idejében segít felülemelkedni az általa okozott zúrzavaron, ami az ismeretek gyors elavulását kíséri.

Profitorientált magániskolák és más, oktatási szolgáltatásokat nyújtó cégek tûnnek fel ajánlataikkal, míg a hagyományos iskolák, főiskolák és egyetemek nehezen tudnak alkalmazkodni a változásokhoz. Technika-uralta világunkban az emberek dolgozók, szülő́k és gyermekeik - mindig is abban bíztak, hogy a tanulás révén jó munkát és társadalmi pozíciót szerezhetnek. Reményeik mellett azonban tele vannak aggályokkal:

(a) A világ nyomasztóan összetettnek tûnik. Az interkontinentális kommunikációs rendszerek révén emberek millióinak létezése vált hirtelen ijesztôen érzékelhetôvé. Mindenféle figyelmeztetés nélkül zúdulnak ránk többszáz ország problémái és válságai.

(b) A technológiai fejlődés egyre gyorsabb és egyre követhetetlenebb. Még az egyetemi oktatók sem ismernek minden folyamatban lévố technológiai újítást, ezekrôl - éppúgy, mint a hallgatók - ók is fóleg a szaklapokból szereznek tudomást.

(c) Nincs idő a bizonytalan, kétes kimenetû helyzetek mérlegelésére. Az üzleti- és karrierlehetôségek meglepetésszerúen bukkannak fel, és azonnali döntést követelve nem hagynak időt a helyzet felmérésére, átgondolására.

(d) Egyetlen munkahely sem biztos többé. Újabb és újabb szakmák tûnnek fel, míg mások eltûnnek. Munkalehetôségek szûnnek meg, az emberek pedig sokszor túl idôsek ahhoz, hogy átképezzék őket. Az új szakmák is elavulnak még az előtt, hogy művelőik aktív életszakasza véget érne. 
(e) Ebben a rohanásban nem csoda, ha az ember nem látja túl fényesnek a jövőt. Ráadásul - legalábbis egyelőre - úgy tưnik, hogy a kormányoknak, amelyek a vékonyka pénztárcánkból befolyó összegekre továbbra is igényt tartanak, nincs sem pénzük, sem konstruktív programjuk arra, hogy ezt a helyzetet hogyan lehetne orvosolni. Olyan oktatásra lenne szükségünk, amelynek segítségével megvethetjük a lábunkat és szilárdan tudunk állni akkor is, ha a változás szele végigsöpör a társadalmon.

A munkaadók, üzletemberek és kormányzati hivatalnokok viszont más perspektívából tekintenek az oktatási rendszerre. Az a céljuk, hogy az intézmények kimúvelt polgárokat és jó munkaerôt képezzenek, nekik is megvannak azonban a maguk aggályai:

(a) A kisvállalkozások száma rohamosan nô. Az üzletemberek olyan alkalmazottakat szeretnének, akik tisztában vannak a vállalkozói lét előnyeivel és hátrányaival.

(b) Az üzletemberek úgy gondolják, hogy az üzleti siker még sohasem függött a mostaninál nagyobb mértékben a számítógépes hálózatok által támogatott társadalmi hálózatok minőségétől.

(c) A vevők elégedettsége, a márkahúség és egyes termékek, szolgáltatások széles körú elterjedése kulcsfontosságú ahhoz, hogy valamely üzlet sikeres legyen. Ehhez olyan alkalmazottakra van szükség, akik - kulturális hátterüktől függetlenül - ezeket az értékeket sugalmazzák a vevőknek és az üzlettársaknak egyaránt.

(d) Az üzletemberek egyre inkább meg vannak gyốződve arról, hogy a „tudni róla" nem vezet el a „tudni hogyan"-hoz. Azt akarják, hogy alkalmazottaik tisztában legyenek az információ és a tudás közti különbséggel.

(e) A vállalkozók tudatában vannak, hogy gazdasági eredményeik növekedése másoktól függ. Olyan dolgozókat szeretnének, akik keményen dolgoznak, húségesek és kitartóak.

A fentiekben két nagy, látszólag egymással szembenálló csoportról beszéltünk. Az egyik oldal azt mondja, hogy az oktatásnak még nagyobb kompetenciát kell kifejlesztenie bennünk, ami a kompetencia legújabb értelmezése szerint inkább specializálódást, kereskedelmi beállítódást és a gyakorlati munkára felkészító tréninget, mintsem általános múveltség megszerzésére irányuló tanulást jelent. A másik oldal szerint viszont általános, széleskörű oktatásra van szükség, ami történelmi rálátást és áttekintést ad, önfegyelemre és felelősségre tanít, és eligazít a kapcsolat- és viszonyrendszerek, a polgári jogok és kötelességek, valamint az identitások területén. Ez a szembenállás nem egyszerúsíthető le az oktatás üzleti és hagyományos megközelítése közti konfliktusra. Mindkét oldalon találunk diákokat, szülőket, üzletembereket és kormányzati hivatalnokokat egyaránt.

Ilyen elvárások mellett lesznek olyan intézmények, amelyek két részre - általános, illetve szakmai oktatást nyújtó fakultásokra - szakadnak szét; és lesznek olyanok is, amelyek csak az egyik feladatra specializálódnak. A nagy többség azonban - attól a vágytól hajtva, hogy az oktatás és a kutatás egy intézményben integrálódjon - létre fogja hozni az egyetem egy új fajtáját, amely ellentmondásmentes lesz és mindkét ol- 
dal elvárásainak megfelel. Amikor ez a pillanat elérkezik, akkor fogja a felsőoktatás a reneszánszát élni. A továbbiakban az eddig felvázolt igényeket vizsgáljuk meg részletesebben.

\section{Egyetemek a XX. században}

Az elmúlt 90 év során a felsôoktatás - a család, az egyház és a helyi közösségek hatásköréből kilépve - nagy állami gépezetté nőtte ki magát. A kis tantermet és a szülőkhöz, tanárokhoz való személyes közelséget felváltotta a diplomások tömegképzése. A közfelfogás nyomására, miszerint a felsőoktatást minden állampolgár számára elérhetôvé kell tenni, az USA szinte valamennyi államában létrejött legalább egy nagy felsőoktatási létesítmény, amelynek a hallgatólétszáma meghaladja a húszezret is. Ezeknek az intézményeknek gyakran több diákjuk van, mint ahány lakosa volt azoknak a városoknak, amelyekben legtöbbünk felnőtt. A nagyarányú létszámnövelés 1960 óta tart. Akkor az egyetemek összköltségvetése 7 milliárd dollár körül mozgott, a hallgatói létszám pedig közel 3 millió volt. Az 1990-es évek közepére az egyetemi költségvetés megközelítette a 170 milliárd dollárt, míg a hallgatói létszám meghaladta a 13 milliót. A költségvetés tehát 30 év alatt a 25-szörösére, a hallgatói létszám pedig több mint a négyszeresére nôtt. Az Egyesült Államokban egyes államok polgárai az oktatási költségeknek csak kevesebb, mint a felét fizetik meg. Míg ötven évvel ezelőtt a normális évfolyamlétszám egy-egy szakon 10-30 fổ között mozgott, ez ma már az alsóéveseknél több száz fő lett, és a felsőéveseknél is megközelíti a százat. A diploma így sokszor nem több mint puszta elismervény arról, hogy valaki bejárt az előírt órákra, és rendesen befizette a tandíjat.

Annak a ma közkeletû́ felfogásnak, miszerint a tudományos kutatás helye az egyetemeken van, az a Wilhelm von Humboldt volt a szellemi atyja, aki 1809-ben megalapította a Berlini Egyetemet. Az egyetem feladata eredetileg az volt, hogy széleskörű tudást nyújtson hallgatóinak és felkészítse ôket a papi hivatásra vagy a politikai pályára. Humboldt szerint az egyetemi tanár tudós, kutató és oktató egy személyben. Ez a felfogás a megszületését követő száz év során uralkodóvá vált mindenütt. Az egyetemek világszerte a tudományos haladás és az intellektuális pezsgés központjaivá váltak.

A második világháború alatt az amerikai kormány nagy összegeket biztosított az egyetemeknek, hogy bizonyos tanszékek kutatói és hallgatói részt vegyenek a háborús problémák megoldásában. 1950-ben egy országos tudományos alap (NSF National Science Foundation), majd az 1960-as évek elején a magasabb szintû kutatások ügynökségének (Advanced Research Projects Agency) létrehozásával ez a gyakorlat intézményes kereteket kapott. Az NSF-re vonatkozó törvényeket az MIT munkatársa, Vannevar Bush 1945-ös jelentése (A tudomány a határtalan tér) alapján fektették le, s ezzel tulajdonképpen egy társadalmi szerződés született meg. Ennek értelmében a kormány szponzorálja a tudósokat, hogy saját kutatási területükön minél jobb eredményt érjenek el, azzal a feltétellel, hogy a jelentôs eredmények - elsôsorban a honvédelem, az egészségügy és a gazdaság területén - az amerikai társadalmat fogják gazdagítani. Az 1980-as évektől az egyetemeknek szánt állami támogatások körét kiterjesztették a nemzetközi versenyképesség növelésének és az ún. „nagy nem- 
zeti feladatok" (National Grand Challenges) végrehajtásának finanszírozására is. Ez vezetett el a „Humán genom” projekthez, valamint az "Ipari kezdeményezés” (Manufacturing Initiative) és a „Nagyteljesítményü számítástechnikai és kommunikációs rendszerek" (High Performance Computing and Communications Program) elnevezésú programokhoz. Ezeknek az állami programoknak a keretében rengeteg pénz állt rendelkezésre, 1993-ban például 800 millió dollárt szántak a nagy teljesítményú számítógépekre, s ennek az összegnek a fele az egyetemek kasszájába folyt be. A kutatások állami finanszírozásának hosszú évei alatt a közvélemény szemében a kutatás vált az egyetemek meghatározó elemévé.

Az egész világ az amerikai oktatási rendszert csodálja, ami nagyrészt a jól szponzorált kutatási programoknak köszönhetô. Sok külföldi diák megy Amerikába azt remélve, hogy az ott szerzett tudást majd hazájában hasznosítani tudja. Az amerikai felsőoktatás ilyen fajta „exportálása” gazdaságilag olyan jövedelmezô, hogy egyes közgazdászok szerint nagyban csökkenti az USA fizetési mérlegének deficitjét.

Valami azonban mégis beárnyékolja az egyetemi kutatások jó hírét. Két fô probléma nehezedik a szövetségi törvényhozók vállára, akik egyébként megkérdôjelezik, hogy a kutatásra fordított rengeteg pénz a humboldti és Vannevar Bush-i értékek kialakulásához vezet. Az első probléma a „publikálj vagy pusztulj” szindróma. Az elmúlt 25 év során szinte minden egyetemen gyakorlattá vált, hogy az új dolgozókról az elsô 6 év alatt eldöntik, hogy alkalmazzák ôket vagy megválnak tôlük. A tudományos hírnévért folyó, szinte univerzális méreteket öltő harc miatt a legtöbb új oktató mindent megtesz azért, hogy cikkei jónevű folyóiratokban jelenjenek meg, és sokan mindvégig kitartanak emellett. Ennek eredményeként évente közel kétmillió publikáció jelenik meg a mintegy 22 ezer tudományos folyóiratban. Ezeknek a cikkeknek a többségét azonban csak néhány száz ember olvassa el. A tudományterületek nagy részében a cikkeknek több mint a felére nem is hivatkoznak. A „publikálj vagy pusztulj” szindróma hatására éppen az veszített az értékéből, ami az egyetemek eredeti célja volt - az oktatás.

Az egyetemi kutatások második problémája az, hogy nem a Vannever Bush által elgondolt lineáris modell szerint alakulnak. E modell szerint a kutatók fejében megszülető gondolatok számos fázison mennek keresztül, a fejlesztéstôl a termelésen át a marketingig, mielőtt fogyasztói termék lesz belőlük. Bruno Latour és Stephen Kline többek között rámutattak arra is, hogy az innovációs folyamat sokkal összetettebb ennél, sok tényezőtôl függ, és ezért tele van visszacsatolásokkal és zavaró tényezôkkel. Elképesztően nehéz tehát bebizonyítani, hogy az innovációs folyamat a kutatónál kezdődik, hiszen sokan mások is részt vesznek benne.

Az elmúlt 30 évben - nagyrészt az állam nyomására - az egyetemek olyan új célokat tûztek ki, mint például a kulturális sokféleség, az etnikai kisebbségek oktatása és a gazdasági versenyképesség. Mindezt attól a meggyőződéstől indíttatva tették, hogy az állam ott tud jobban múködố társadalmat kiépíteni, ahol kisebb az etnikai feszültség, kevesebb a betegség, ritkább a diszkrimináció, továbbá alacsonyabb arányú a szegénység és a munkanélküliség. Ennek az lett az eredménye, hogy még nagyobb hangsúly került a bürokráciára, az oktatásra pedig még kevesebb energiát tudtak fordítani.

A Columbia Egyetemen dolgozó Eli Noam professzor szerint az Internet és a digitális könyvtár „divatjamúlttá” teszi az egyetemi könyvtárakat és a kutatók egyetemi közösségét. Az e-mail, a telefon, a fax és a sugárhajtású repülőgépek ugyanakkor 
megkönnyítették, hogy a különbözô egyetemeken mûködő kutatók szorosabb kapcsolatokat építsenek ki egymással, mint amilyenekkel a saját intézményükön belül rendelkeznek. Az információtechnológia tehát hanyatlással fenyegeti az évszázadok során létrejött hagyományos egyetemi formát, és új alapokat teremt az egyetem számára.

\section{Üzleti struktúra}

„Értékvándorlás” (Value Migration) címú könyvében Adrian Slywotzky „üzletstruktúráról” beszél. Ez alatt azt a mindent átfogó szerkezeti vázat érti, amelyre egyegy üzleti vállalkozás épül: a stílust, a megközelítési módokat és az alapfeltevéseket. A legtöbb üzleti vállalkozásban megtaláljuk a kutatási, fejlesztési és marketing tevékenységeket (KF\&M), amelyek eredményeként egy új termék vagy szolgáltatás létrejön, és amelyek a vállalat üzletstruktúrájának részei. Mi történik, ha maga a váz, vagyis az üzleti struktúra válik elavulttá? A KF\&M folyamatok nem tudják versenyképessé tenni a céget? Ez többször megesik, mint gondolnánk, sôt, olykor nagyon is látványosan. Az IBM és a Digital Equipment Corporation üzletstruktúrája nagyon jól múködött mindaddig, amíg a Microsoft tömegesen értékesíteni nem kezdte a szoftvereit. Késóbb a Microsoftra került a sor: meg kellett birkóznia a Netscape és a Sun Java kihívásával. A posta számára a gyorsfutárszolgálatok és az e-mail szolgáltatások jelentenek nagy kihívást.

Amikor egy új cég jobb szolgáltatásokat ígér, az ügyfelek átpártolnak hozzá. Ha egy régebbi cég úgy „tálalja” termékeit és szolgáltatásait, hogy azokat az ügyfelek nem tartják többé vonzónak, ez a cég valószínúleg nem tud már olyan termékekkel és szolgáltatásokkal megjelenni a piacon, amelyekkel visszahódíthatná a vásárlókat.

Mi történik abban az esetben, ha egy egyetemnek van elavult üzletstruktúrája? A magánegyetemek viszonylag gyorsan reagálnak a jelentkezések csökkenésére, az állami egyetemek általában jóval lassúbbak. Azoknak, akik nincsenek megelégedve az állami felsốoktatással, két választásuk van: vagy átmennek egy magánegyetemre (jóval nagyobb összegú tandíj mellett), vagy a politikai vezetést hibáztatják és panaszkodnak. Elegendő panasz láttán a politikai vezetés vagy új törvényeket hoz, hogy még szigorúbb szabályozás alá tudja vonni a bajban lévô intézményeket, s ezzel még inkább rákényszerítse ốket egy elavult rendszer fenntartására; vagy népszerúbb programokra csoportosítja át a költségvetési kereteket.

A piaci és a politikai erők kétségtelenül új egyetemi struktúra létrejöttét sürgetik. A kérdés csak az, hogy ki melyik oldalon áll, valamint az, hogy a hallgatókért folytatott küzdelemben milyen új versenytársak tûnhetnek fel. A jelenkor egyeteme fenyegetett helyzetbe került, melyben nemcsak az egyetem hagyományos üzletpolitikája a tét, hanem olykor a fennmaradása is. Ugyanakkor rengeteg új lehetôség nyílik arra, hogy a felsốoktatás színvonala emelkedjen, és az egyetemek életképes szakmákra és tartalmas életre tudják felkészíteni a hallgatóikat. 


\section{Miért van szükség a változásra?}

A XX. század végén az egyetemi oktatás fốbb jellemzői a 4 éves képzési idő, a nagy létszámú évfolyamok, a féléves vagy negyedéves tanmenetek és a féléves vizsgarendszer. A hallgatók a kredit-tárgyak eredményes teljesítése után diplomát szereznek; az alapkutatási programokban többnyire csak a magasabb szintú tanulmányokat végzô hallgatók vehetnek részt. Egyes egyetemek az alapképzésen kívül kiegészítő programokat is nyújtanak. Ezt a szerkezetet nem lehet az oktatással szemben támasztott igényeknek megfelelően átalakítani. Így például nem lehet bevezetni egy olyan magasabb szintű programot, amelynek célja a kompetencia megszerzése egy bizonyos területen, hiszen az egyetem az eddigi hagyomány szerint - a PhD kurzusok kivételével - nem ad helyet olyan kurzusoknak, amelyekben a hallgatók különbözó teljesítményszinten vannak, de a végeredmény mindig azonos. Az egyetemek leginkább olyan kurzusokat kínálnak, amelyeknél - fix képzési idố mellett - változó a végeredmény.

Azt, hogy a hallgatóknak, a szülóknek, a munkaadóknak és a vezető üzletembereknek milyen új elvárásaik vannak a felsőoktatással szemben, könnyen megtudhatjuk az általuk megfogalmazott igényekből és panaszaikból. Ezek között három fổ csoportot különböztethetünk meg:

(1) Amit tanulunk:

- Az intézmény általános képzést ad, ami az emberi civilizáció alapértékeit erősíti bennünk, fejleszti a történelmi tudatot, s képessé tesz társadalmi kapcsolatok kialakítására és a társadalmi hálózatba való beilleszkedésre, valamint arra is, hogy felelősségteljes és értelmes szakmai, családi és magánéletet éljünk.

- Azokra is gondol, akik középiskolai tanulmányaik alapján még nincsenek teljesen felkészülve az egyetemi tanulmányokra.

- Gondoskodik azokról, akik az átlagnál jobb képességekkel rendelkeznek.

- Saját érdeklődési területünkön vállalkozó szellemúvé tesz bennünket.

- Megtanítja, hogyan tudunk az egyre komplexebbé váló és a technológia által egyre inkább átszőtt világban eligazodni.

- Az első egyetemi diploma megszerzése után további szakmai képzést biztosít.

- Akkreditált képzést nyújt bizonyos szakmákhoz, ideértve például a szoftverés hálózat-tervezést is.

- A tartalom és nem a teljesítmény a fontos.

- Olyan ritka, interdiszciplináris területekről is tanulhatunk, mint például a bioinformatika.

(2) Ahogyan tanulunk:

- Az intézmény olyan tanulási környezetet biztosít, ami alkalmazkodni tud a hallgatók különféle társadalmi hátteréhez, tanulási stílusához, munkabeosztásához és eltérō érdeklődési területeihez.

- A kurzusok megtervezésénél figyelembe veszi a dolgozók munkabeosztását.

- Több képzést biztosít a pályakezdôknek.

- Pusztán az információ visszaadására való képesség helyett cselekvóképességet (gyakorlati kompetenciát) szavatol. 
- Az egyetem egyedi oktatási anyagokat, szemináriumokat és szolgáltatásokat nyújt.

- A tantervben szerepel az Internet útján történô képzés is, s ha valaki ezt a képzési típust választja, nem esik el a nappali képzéshez való jogától.

- Olyan tanárok oktatnak, akik jó vezetői képességekkel rendelkeznek, erősen motiválni tudják, inspirálják és alaposan felkészítik a hallgatókat.

- Az oktatókat a hallgatók eredményei alapján minôsítik, nem pedig egy-egy órájuk és kutatói teljesítményük alapján.

(3) Társadalmi szerződés a kutatásért:

- A kutatásokat az üzleti szektorral együttmúködésben végzik, egészen a végtermékig.

- A magasabb szintû́ képzésben résztvevố hallgatókat bevonják a kutatásba

- Nem sajnálják az időt arra, hogy az eredményeket érthető formában rögzítsék, hogy azoknak a gyakorlatban hasznát lehessen venni.

- Megtanítanak arra, hogy amikor választ keresünk kérdéseinkre, a ránk zúduló információtömegből hogyan válasszuk ki, mi a fontos és mi nem az.

Ezeken a területeken olyan nagy nyomás nehezedik az egyetemekre, hogy a jelenlegi gyakorlaton elóbb vagy utóbb változtatniuk kell. Alapvetô szerkezeti átalakításokra van szükség az alapképzésben és a magasabb szintû szakmai képzésben egyaránt, beleértve a képesítéseket, valamint a tanulási, oktatási és kutatási gyakorlatot is. A változtatások révén az oktatás és a kutatás viszonya is új értelmezést nyer, s így feloldódnak a konvenciókban gyökerezố ellentmondások.

Egyáltalán nem biztos, hogy minden egyetem végigjárja ezt az átalakulási folyamatot. Lesznek olyanok, amelyek átalakulnak és sikerrel járnak; lesznek olyanok, amelyek nem, s végül lesznek olyanok is, amelyek végleg megszúnnek. A magánintézmények egyre sikeresebbé fognak válni, s elképzelhető, hogy uralni fogják az oktatási piacot.

\section{Az igazi tudás}

Újra és újra felmerülő probléma a kompetencia kérdése. Mind a tanulók, mind a munkaadók olyan oktatási programokat akarnak, amelyek garantálják bizonyos készségek megszerzését, és erről bizonyítványt adnak. Ez egyáltalán nem meglepő, hiszen egyrészt nagyon sokan gondolkodnak úgy, hogy diplomásként jobb munkalehetôségekhez jutnak, másrészt pedig sok munkaadó közvetlenül az egyetemekről toborozza leendố alkalmazottait. Az oktatók mégis gúnyosan mosolyognak, mert számukra a „kompetencia” ilyen gyakorlatias, hétköznapi értelmezése nem más, mint burkolt „szakbarbárság”, és erôteljesen vitatják, hogy ennek kialakítása az egyetemek feladatai közé tartozna. Véleményük szerint az egyes szakmai készségek hangsúlyozása egyre nagyobb specializációhoz fog vezetni, ami az egyetem másik feladatának, az általános múveltség kiterjesztésének a háttérbe szorulását fogja eredményezni.

Ebben a kérdésben az oktatók között sem teljes az egyetértés. Sokan vannak, akik éppen ilyen erôteljesen érvelnek a szaktudásra épülő kurzusok mellett. Szerin- 
tük a hallgatók mindaddig nem mehetnek át a vizsgán, míg kellőképpen nem demonstrálják, hogy tudják és alkalmazni is képesek a tananyagot. Hogy megnyugtassák kollégáikat, ezek az oktatók azt mondják, hogy ốk tágabban értelmezik a kompetenciát, amibe nagyon sok minden belefér: a számítógépek múködtetése vagy szoftverek kidolgozása, a köznyelv, a retorika, a vita, a kritikus gondolkodás, a történelem elemzése, a csoportmunka, a csoportirányítás és a csoportvezetés. A közfelfogás szerint, ha valaki kompetens valamiben, akkor ismernie kell az adott szakterület kialakulásának történetét, módszereit, céljait, határait, aktuális problémáit és más szakterületekkel való kapcsolatait; s mindezeknek az ismereteknek a birtokában képesnek kell lennie az elvárt színvonalon vagy a fölött teljesíteni feladatait az adott területen. A képesítés nem más, mint a kompetencia hétköznapi elnevezése. Néhány szakterületen például a múszaki tudományok, az oktatás, a számvitel, a jogtudomány vagy az orvostudomány területén - a képesítés megszerzése speciális és szigorú feltételekhez van kötve. A képesítés szükséges vagy legalább is kívánatos a szakma gyakorlásához.

Ez a nézetkülönbség az elsô jele annak, hogy az adat, az információ és a tudás fogalmának a megítélése kezd megváltozni. Egyre inkább bekerül a köztudatba, hogy alapvető különbségek vannak e három fogalom között: (1) Az adat kézzel vagy más eszközzel létrehozott szimbólum. (2) Az információ ítélet, melyet egy személy vagy egy csoport hoz arról, hogy egy adat vagy adathalmaz választ ad-e a felmerüló kérdésekre, felfed-e eltéréseket, illetve lehetôvé teszi-e a továbblépést, vagyis az információ nem más, mint valaki(k) számára többletjelentéssel bíró adat vagy adathalmaz. Az információ tehát függ az egyéntốl; ugyanazok az adatok valakinek aranyat érnek, másnak meg éppen semmit sem. (3) A tudás a megfelelő cselekvésre való képesség.

Lewis Perelman a három kategória közti eltéréseket egy étlaphoz hasonlítja. Az étlapon lévő szimbólumok az adatok; az étterem kínálatának megértése az információ; a tudás pedig maga a „vacsora”, az étkezés. Nem a tintát szoktuk lenyalogatni, vagy esetleg magát az étlapot megenni.

Ezek a különbségek nincsenek elég határozottan kimondva a felsőoktatásban. A legtöbb tanterv azon a feltevésen alapszik, hogy egy adott tudásanyagot (vagyis a felhasználók számára információértékű adatok halmazát) kell a hallgatókhoz eljuttatni. Ehhez a tanár alkotja a kommunikációs csatornát. Az egyetemek többnyire csak az étlapig jutnak el. Segélykiáltásunk a kompetenciáért pedig - „vacsora hiányában” - nem más, mint éhségérzetünk kifejezése.

Ez a segélykiáltás is annak a jele, hogy kétféle tudás létezik. Az egyik a gyakorlati tudás, az a képesség, ami a cselekedetek mögött áll. Elég gyakorlással és felkészüléssel ezek a készségek fejleszthetôk. Hat szintet különböztethetünk meg: kezdő, újonc, szakmabeli, szakértő, virtuóz és mester. Minden szinten egy bizonyos teljesítményszintet kell elérni. Akár évekbe is telhet, hogy egyik szintről egy magasabb szintre jusson az ember. A készségek fejlesztésére a szakmai gyakorlat a leghatékonyabb módszer.

A másik tudásfajta megfigyelői szerepünkhöz társul. Mindannyian tele vagyunk nézetekkel és előítéletekkel, amelyek hatással vannak arra, amit érzékelünk. Sok dolgot nem veszünk észre, s azt sem vesszük észre, hogy nem vettük őket észre. Megfigyelői énünk tehát hatással van asszociációs képességünkre, s így arra is, hogy adott szituációban hogyan cselekszünk. Mindenkinek vannak olyan pillanatai, amikor a megfigyelői énjében változás következik be, s új cselekvési lehetôségeket lát meg. 
Ezt a paradigmaváltást nevezhetjük „aha-élménynek”, „heuréka-pillanatnak” vagy hirtelen felismerésnek. Ezek a váltások - a készségek elsajátításának folyamatától eltérốen - hirtelen történnek és azonnali hatással vannak teljesítményünkre. A jó tanárok és gyakorlatvezetők tudják ezt.

Egy másik személy megfigyelőkészségét megfigyelni is elég nehéz feladat, a sajátunk megfigyelése viszont lehetetlen. Ezért olyan nehéz egy egész közösségi rendszert - például egy egyetem struktúráját - megváltoztatni. A legtöbben nincsenek tisztában azzal, hogy hogyan látják a világot, és ezért nincsenek tudatában annak a lehetőségnek sem, hogy esetleg éppen a legkézenfekvôbb megoldásokat nem veszik észre. Speciális vezetői képességek kellenek ahhoz, hogy egy közösség szeméról lehulljon a hályog.

Amikor ezek az alapvető különbségek tudatosodnak, nagy változások fognak bekövetkezni az oktatásban. A tanár-diák kapcsolat átalakul „újonc-mester” kapcsolattá, és biztos útként vezet majd a tudáshoz. A tanárnak speciális készségekre lesz szüksége, de nem az információátadáshoz, hanem ahhoz, hogy megfigyelésre és felismerésre késztesse a tanulókat. Az általános és szakmai képzés közti ellentmondások meg fognak szúnni. Az általános oktatásnak az a célja, hogy a hallgatók a gyakorlatban is hatékony olvasási, írási, beszéd- és megfigyelési készségekkel hagyják el az egyetemet; továbbá tájékozottak legyenek a történelem, az irodalom, a nyelvek és a társadalmi kapcsolatok terén. Ez az általános alap nyújt megfelelő hátteret ahhoz, hogy valaki a kompetencia magasabb szintjeire is el tudjon jutni.

\section{Hipertanulás}

Lewis Perelman „Az iskola alkonya” címú könyvében élénk képet fest arról, hogy a fentebb említett erôk miatt milyen változások elôtt áll az oktatás. Szerinte a mai iskolarendszernek a változással szemben tanúsított ellenállása hasonló ahhoz, ahogyan a tizenkilencedik században a lovaskocsikat üzemeltetô társaságok a „ló nélküli szekér" érkezését fogadták, vagy ahhoz a bizalmatlansághoz, ami a gyertya- és gázvilágítást felváltó elektromos világítás megjelenését övezte. Az automobilok végül teljesen kiszorították a lóvontatta jármûveket, az elektromosság pedig a gázvilágítást. A jövô történészei úgy írnak majd a huszadik század végének iskolai reformmozgalmairól, mint amelyeknek éppen úgy nincs közük az új világ oktatási rendszeréhez, mint ahogy a lovas közlekedési reformoknak sem volt közük az automobilhoz. A tanulás forradalmában a tanár hagyományos osztálytermi szerepköre olyan fölösleges és elavult lett, mint a patkolókovácsé. Perelman a kialakulóban lévố új tanulási módot hipertanulásnak nevezi. Éppúgy, mint a matematikában a „hipertér” vagy a nyelvészetben a „hipertext” esetében, a "hiper” elôtag itt is a környezet nem-lineáris, sokdimenziós voltára utal.

A hagyományos iskolamodellben egy kurzuson belül adott témaköröket visznek végig, az órákat hetenként, tanteremben tartják és az órák közti időszakra a hallgatók házi feladatot kapnak. Ez a lineáris tanulási modell, amit úgy alakítottak ki, hogy az információkat meghatározott sorrendben közvetítse. Így elméletileg minden tanuló azonos ütemben halad előre, függetlenül attól, hogy mi az érdeklődési területük, milyen előzetes tapasztalatokkal rendelkeznek, mihez van tehetségük vagy milyen spe- 
ciális igényeik vannak. A kurzus végén az osztályzatok jelzik, hogy a tanulók egy adott, előre meghatározott idő alatt milyen szintre jutottak.

Képzeljünk el egy új modellt. A tanterem helyett képzeljünk el egy „tanulószobát”, amelyben tanulófülkék vannak, a szobának egy bejárata és egy kijárata van. A tanár kisebb csoportokra osztja a tanulókat. A szoba kijáratánál a „képesítô” áll ôrt, akinek az a feladata, hogy előre lefektetett szempontok alapján felmérje, a tanuló eljutott-e a tanár által meghatározott kompetenciaszintre. Az egyes fülkékben különbözố témákban lehet tárgyi és gyakorlati tudást szerezni. A padlón színes vonalak mutatnak egy ajánlott haladási útvonalat. A tanulók a záróvizsgára való felkészülés során annyi fülkébe mennek be, amennyire szükségük van, olyan sorrendben, ami az aktuális tudásszintjüknek megfelel. Próbavizsgákat is tehetnek, s az eredményeknek megfelelően fejleszthetik tovább magukat. Bármikor kitölthetnek önértékelő teszteket. Projekteken dolgoznak, kisebb-nagyobb csoportokra osztva. Ha megakadnak, bármikor kérhetik a tanár segítségét. Ha rossz irányban haladnak, a tanártól útbaigazításokat kaphatnak. A lineáris modellel ellentétben itt mindenki, aki „kilép” a szobából, ugyanazt az „osztályzatot” kapja: bizonyítványt arról, hogy sikeresen befejezte tanulmányait, vagyis bizonyítványt a kompetenciáról. Ennek a modellnek a változó tényezôi a képzési idố hossza és az „útvonal”. Bár ez még nem a hipertanulási modell végső, kiforrott formája, nagyon jól szemlélteti az első próbálkozásokat.

Úgy tưnhet, hogy ebben a modellben minden tanuló egyforma, és így a tehetséges, jobb képességû tanulóknak nincs elegendő lehetôségük arra, hogy fejlesszék magukat. Ez nem így van. A tehetségesebb tanulók rövidebb időn belül hagyhatják el a szobát és továbbmehetnek, hogy a többieknél magasabb szintű képesítéseket szerezzenek.

Ennek a modellnek nagyon fontos alkotóeleme a szintfelmérô vagy képességvizsgáló teszt, ami tulajdonképpen nem más, mint egy digitális tanársegéd, amelynek az a feladata, hogy felmérje, egy tanuló mikor teljesítette a kurzus-követelményeket, és errốl hiteles bizonyítványt adjon. Az ilyen „ügynököknek” már létezik az elsô generációja, de ezek egyelôre még nem elég hatékonyak. Még mindig tudományosan levezethetô, kiszámítható válaszokat keresnek a problémákra, s ehhez feleletválasztós vagy kitöltôs teszteket használnak. A jövôben valószínúleg intelligens „ügynököket” is találunk majd a vizsgáztatók között, és a virtuális valóság technikai eszközeivel készült szimulációkat fognak használni. Az is elképzelhetô, hogy interaktív beszélgetés keretében egy egész bírálóbizottság fog kérdéseket feltenni vagy utasításokat adni a vizsgázónak. Ezek az eljárások az önértékelő tesztekkel együtt lehetőséget adnak arra, hogy a tanulók felmérjék felkészültségüket már a képesítő vizsga elôtt, vagy mielő́tt egy új tanulási környezetbe lépnek. Előbb vagy utóbb nagyon jó hipertanulási környezetet fogunk létrehozni, ami alkalmas lesz arra, hogy egy-egy szakmára vagy szakterületre megfelelően felkészítse a tanulókat.

\section{Szakmai képzés}

Az egyetemek és fôiskolák jelenlegi tananyaga olyan hallgatóknak készült, akik a középiskolából kikerülve négy év alatt diplomát akarnak szerezni. Ezután még további egy vagy két évig folytathatják tanulmányaikat magasabb szinten, az úgyneve- 
zett master's programok keretében. Ezen túl az elkövetkező 45 évre már elég szegényes az egyetemek kínálata, ha valaki szakmai továbbképzést akar. A továbbképzési programok általában nem tartoznak bele az általános felsőoktatási tantervekbe és vagy az egyetemeken kívül, vagy csak a magasabb szintû́ tanulmányok keretein belül folynak.

Egyre több szakember akar csupán bizonyos szakterületekrôl képesítést szerezni, mert ez a munkahely szempontjából számukra (és a munkaadójuk számára is) értékesebb. Olyan képzési programokat akarnak, amelyek az adott szakterületen folytatott munkájukhoz szükséges ismereteiket és készségeiket fejlesztik. Olyan - a változásokat követő és egyre szélesebb körü - szakmai képesítô rendszert szeretnének, ami nem független az alapképzéstől, hanem arra épül és kiegészíti azt. A szakmai képesítéseknek olyan nagy lesz a piaci értékük, hogy akár ki is szoríthatják a felsőoktatásban szerzett okleveleket.

A szóban forgó igényeknek kétféle oktatási program felelhet meg, amelyek a tudás már korábban említett két fajtájára (a „tudni hogyan” és a „tudni róla” fogalmaira) vezethetốk vissza. Az egyik fajta program elvégzésekor a tanulók egy adott területen szerzett kompetenciájukról szereznek bizonyítványt. Ide tartoznak például a hálózattervezés, a tudományos számítások, a biomolekula-építés, a középiskolai matematika-tanítás vagy a statisztikai analízis témái. Ezeknél a programoknál a képzési idő körülbelül egy év. A másik fajtához tartozó program a tanuló nézőpontját változtatja meg. Ilyen lehet például egy időszerú probléma tanulmányozása (pl. „Hogyan tudja egy vállalkozás a termékek szállítására fordított időt csökkenteni?”), a közoktatás újszerû megközelítése (pl. „A mindentudás korában mirôl tájékoztat minket a nyelvfilozófia?”), vagy egy adott területtel való megismerkedés (pl. „Biztonság és adatvédelem a hálón”). Az ilyen programok képzési ideje néhány naptól néhány hónapig terjedhet.

Néhány egyetemen olyan rendszert használnak, amelyben a tanuló akkor kap képesítést, ha meghatározott kurzusokon „A” vagy „B” minősítéssel végzett. Ez nem elégíti ki a fentebb említett igényeket. A szakmai képzést nyújtó programok speciális területeken szerzett kompetenciáról és készségekrôl adnak képesítést, szigorú projektmunka és tesztelés jellemzi majd őket, és addig tartanak, amíg a tanuló el nem jut egy adott kompetenciaszintre. Ilyen programokat megtervezni és beilleszteni az egyetemek kurzuskínálatába nehéz lesz, hiszen ezekben a programokban - a hagyományos képzési modellel éppen ellentétben - fix a végeredmény, de a képzési idő változó.

A szakmai képzésben a kurzusok megtervezésénél a dolgozók munkabeosztását is figyelembe kell venni. Épp ezért az új kurzustípus formai keretei is megváltoznak: ezek inkább „múhelyek” lesznek, ahol a munkacsapatok egy-egy projekten dolgoznak, s az Interneten keresztül tartják a kapcsolatot, majd beszámolnak eredményeikről. A hagyományos osztálytermi óra századrangú választási lehetőség lesz.

Ezáltal lehetségessé válik, hogy olyan képzési programok szülessenek, amelyek magasabb szakmai szintekre is el tudják juttatni a tanulót, a szakértôi szinttôl a virtuozitáson keresztül egészen a mester szintjéig. A jelenlegi képzési formák esetében ezek a szintek csak a szakmai karrier későbbi szakaszában érhetôk el. Az új rendszer termékeny és még kiaknázatlan területet kínál az egyetemek számára. 


\section{Az új tanár}

Az a nyomás, ami arra ösztönöz bennünket, hogy megújítsuk a tanterveket, ki fogja kényszeríteni az oktatás forradalmasítását is. Az oktatási gyakorlat úgy fog megváltozni, hogy megfeleljen az új egyetemek elvárásainak, az új tanterveknek és a „hipertanulás” követelményeinek. A változások hajtóerejét két tényező biztosítja. Az egyik az, hogy a diákok az eddiginél inkább fogyasztó-orientált attitûdöt várnak el az egyetemtôl. Az egyetemi oktatóknak ezért az odafigyelés, a szavahihetôség, a jóindulat és emberszeretet, a szolgálatkészség, a változatosság megbecsülése, a kommunikáció és a történelmi tudatosság terén olyan új készségeket kell elsajátítaniuk, amelyeket nemcsak a diákokkal való kapcsolatteremtésben használnak, hanem át is adják ezeket az értékeket a hallgatóknak.

A változások másik mozgató rugója a digitális média és a hálózat. A mai oktatók olyan környezetben nőttek fel, ahol a tanítás többnyire előadásból és számonkérésből állt. A tanár munkáját - óralátogatások alkalmával - kollégái ellenőrizték. De vajon mi lesz a tanár feladata, ha eltúnik a tantermi oktatás és az előadások nagy részét gépek fogják vezérelni, nem ritkán jobban, mint egy élő előadó, s a számonkérést és az eredmények nyilvántartását szintén gépek végzik?

Mint korábban kifejtettük, a tanár feladata a diákok tudásának csiszolása. Ez a feladat legjobban a „tisztás” metaforáján keresztül mutatható be, ami azoknak a tevékenységeknek a körét jelenti, amelyeket egy közösség tagjai végeznek. Ez a metafora egy olyan helyre utal az erdőben, ahol könnyen mozoghatunk, de ha kilépünk onnan, az aljnövényzet akadályozza a mozgást. A humán értelemben vett „tisztás” egyik értelmezése a közösség, amit a közös meggyőződések és a megszokott gyakorlat tartanak össze. Az újonnan érkezónek - ahhoz, hogy magabiztosan mozoghasson a tisztáson - az ösztönös alkalmazás szintjéig el kell sajátítania ezt a gyakorlatot. Alkalmazkodnia kell, és a közösség részévé kell válnia. Aki szembeszegül a közösséggel, nagyon hamar az aljnövényzet ellenállásával találhatja szemben magát: a többiek akár teljesen ki is közösíthetik, ha a közösségre veszélyesnek ítélik meg. Ennek értelmében a tanár feladata három fő részból áll:

1. Tudatosítani a diákokban annak a közösségnek a mibenlétét, amely azon a „tisztáson” él, ahová késốbb be szeretnének kerülni.

2. Bemutatni a diákoknak, hogy a „tisztás” bevett szokásai milyen hálózatot alkotnak. Ez magában foglalja annak az ismertetését, hogy a történelem során hogyan és miképp jött létre az adott hálózat, mik a módszerei és szokásai, céljai, határai, aktuális problémái és kapcsolatai más „tisztásokkal”.

3. Olyan felkészítést és gyakorlatokat biztosítani, amik segítik a hallgatókat abban, hogy tanulmányaik során felfedezzék a „tisztásokat” és azok szokásait magukévá tegyék, hogy majd késóbb ezek az ismeretek és képességek rögzüljenek és rutinná váljanak náluk.

Fontos világosan látnunk, hogy az új elôadási, számonkérési és eredmény-nyilvántartási technológiák megjelenésével maga a tanítás nem válik elavulttá. Éppen ellenkezőleg, a tanártól azt fogják elvárni, hogy inspirálja, ösztönözze, irányítsa és felkészítse a diákokat. Kevesen vannak a tanárok között, akik képesek ezekre a felada- 
tokra, egyrészt azért, mert nem voltak rákényszerítve az elsajátításukra, másrészt pedig azért, mert nem volt senki, aki megtanítsa őket ezekre. A jövőben új és átfogó fejlesztési programok fogják segíteni őket, hogy kiemelkedően hatékony tanárokká váljanak. Ezekben a programokban a következő fontos témák fognak megjelenni:

- Az oktatás célkitûzései

- Adatok, információ és tudás

- Az oktatási technológia szerepe

- A nyelv használata (önkifejezés, másokkal való összehangolódás és tájékozódás)

- „Tisztások”

- Müveltség

- Kommunikáció

- Figyelem

- Vonzóeró

- Bizalom

- Jóindulat és emberszeretet

- Tisztelet és önbecsülés

- Szolgálat

- Mások megbecsülése és elismerése

- Színes egyéniség

- Komolyság és humor

- Felfedezés és újítás

- Történelmi tudatosság

- Játékok és szimulációk

- Új tanulás-irányítási módszerek

- Felkészülés olyan feladatokra, amelyek segítik a tanulókat abban, hogy helyesen tudjanak szemlélődni és tanulni

A fenti témákban azonban sajnálatos módon nem elegendô pusztán egy jó, múhely-jellegú tanfolyam. A tanítási módszerek elválaszthatatlanok a tantervtôl, és a jelenleg érvényben lévố tantervek nem adnak teret az új módszereknek. A mûszaki tantervek például az intenzív előadásokhoz hasonló módon, jól meghatározott sorrend szerint vannak megszerkesztve. Ebbe a rendszerbe nem egykönnyen illeszthetők bele játékok és szimulációk, vagy olyan mérföldkövek, amelyeken csak a szakértelem bizonyítása után lehet túllépni.

A fogyasztóközpontú szemlélet és a gépekkel vezérelt tanulás hajtóereje kétségtelenül abba az irányba visz bennünket, hogy átformáljuk a tanrendeket és a tanítási gyakorlatot. Csupán az a kérdés, hogy ez mikor fog bekövetkezni.

Azok a kilátások, amikkel ez az átalakulás kecsegtet, minden bizonnyal sok egyetemi oktatót felkavarnak. Sokan meg fognak botránkozni azon a változáson, hogy a diákokat olyan fogyasztókként kell kezelniük, akik elvárják tôlük, hogy szigorúan megfeleljenek azoknak az ígéreteknek, amikkel az oktatási rendszer kecsegteti óket. Az előadásközpontú tanítási módszer megszűnése ráadásul a tanári teljesítmény új értékelését vonja maga után. A tanárok helyzete leginkább ahhoz fog hasonlítani, ami- 
vel egy üzleti vállalkozás vagy egy futballcsapat menedzsere szembesül. A menedzser teljesítménye ugyanis leginkább csapatának teljesítménye alapján mérhetố le. A tanárokat pedig annak alapján fogják értékelni, ahogyan a diákjaik teljesítenek. Semmi más nem fog számítani.

\section{Úi társadalmi szerződés a kutatásról}

A kutatásról kialakult, immár 15 éves társadalmi szerződés lassan érvényét veszti. De mi fogja felváltani? A huszonegyedik század kutatási „képletét” talán - éppúgy, mint ahogy a modern kutató egyetem koncepciója egy német egyetemen született meg - szintén egy német kutatóintézetben fogják felfedezni. Dennis Tsichritzis, a GMD nevú német kutatóintézet vezetôje a lehetséges újításokkal foglalkozik: az érdekli, hogy hogyan lehet emberi közösségek konvención alapuló gyakorlatait úgy megváltoztatni, hogy azok hatékonyabban múködjenek. Szerinte a kutatás lesz az innovációhoz vezető út. A modern kutatóegyetem munkáját az a tévhit akadályozza, hogy az innovációhoz egyetlen út, nevezetesen új elméletek kidolgozása vezet. Az újításokhoz azonban legalább négy különbözố folyamat vezethet el:

1. Új elméletek megalkotása. Az új, nagyhatású elméletek megváltoztatják a tudományos fogalmakat, s ezáltal az elgondolásokat és az ezeknek a megvitatásában résztvevő́k tevékenységét is. A kutatás az új elméletek kialakításából és teszteléséből áll. Nagyon lényeges az elméletek eredetisége és újszerűsége. A tudományos publikációk célja pedig éppen az eredeti és újszerű elméletek megismerésének biztosítása a folyóiratokban való közlés és a referenciák útján.

2. Új alkalmazások kialakítása. Egy tanár bevezeti a diákokat az új elméletek alkalmazásába. A kutatás feladata itt az alkalmazáshoz szükséges alapelvek kiválogatása, tisztázása és integrálása. Nagy hangsúlyt kap a tájékoztatás, ami a szakértelem széleskörű elterjedését teszi lehetôvé.

3. Új termékek előállítása. Az új eszközök új módszereket, hatékonyabb termelést és innovációt tesznek lehetôvé. Ezek közül azok a legsikeresebbek, amelyek abban segítenek, hogy az emberek önállóan hozzanak létre újításokat a saját környezetükben. A kutatás szerepe az, hogy értékelje és tesztelje az eszközök kialakításának különböző módjait és funkciót rendeljen az eszközökhöz. Ebben az esetben a gazdaságosság kap nagy hangsúlyt.

4. Új üzleti megoldások létrehozása. A sikeres vállalatok folyamatosan fejlesztik üzleti stratégiájukat. A kutatás feladata a piac ellenőrzése, a fogyasztók véleményének felmérése, a szokatlannal, a konvencióktól való eltéréssel foglalkozó projektek végrehajtása, valamint új elképzelések kialakítása az emberek szerepérôl és helyérôl a világban.

Tsichritzis ugyan nem határozza meg az innovációnak ezt a négy típusát, de egyértelmúen alkalmazza ôket a GMD vezetésében.

Az első két típus fő́ként az egyetemeken található meg, míg az utolsó kettô fơleg a vállalatoknál. A harmadik típusú kutatási és fejlesztési $(\mathrm{K}+\mathrm{F})$ az iparban a leggyakoribb, és sokszor az egyetemek és az ipari vállalatok közötti együttmúködésen 
alapul. A legtöbb nyilvánosan ismertté vált innováció közvetlenül a harmadik típusú kutatásnak köszönhető, közvetett módon pedig az elsőnek.

A kutatás második típusát gyakran lenézik, ennek a szerepe azonban az egyéni és a szervezeti szakértelem kialakításában kiemelkedően fontos. Sok egyetemi dolgozó messzemenően alkalmas arra, hogy ilyen jellegú kutatásokat végezzen. Ezek tudományos munkájuk során különféle kérdéseket vizsgálnak, összegzik az eredményeket, integrálják felfedezéseiket, tisztázzák a kérdéseket, új értelmezéseket dolgoznak ki, és témájukat mások számára is érthetővé teszik. Népszerűsítő cikkeket és könyveket írnak, oktató berendezéseket, eszközöket és szoftvereket dolgoznak ki. Kutatási eredményeikről tudományos közleményeket írnak és konferenciákat látogatnak, s ennek köszönhetôen ismereteiket naprakészen tartják és diákjaiknak modern kutatási módszereket tudnak tanítani. Így fenntartják a bizalmat abban, hogy a kutatók a vezetố technológiák és elméletek birtokában vannak.

A tudományos világban hagyományosan a kutatás elsố típusának van a legnagyobb presztízse. Azok kapják a legnagyobb elismerést, akik ebben sikeresek. Erre azonban nem mindenki alkalmas; vannak, akik kitartóan és erőszakosan próbálkoznak, de csak ritkán érnek el sikereket. A hagyományok azonban idôvel utat fognak engedni a gazdasági realitásnak. Ahogy az egyetemek alkalmazkodnak ahhoz, hogy az alapkutatások vagy más néven „kíváncsiság által motivált” kutatások állami támogatottsága egyre szúkül, az elsố típusú kutatás olyan jól felszerelt laborokba fog átkerülni, ahol azok dolgoznak, akik éppen ebben a legjobbak: kreatívan gondolkodók, szabadúszók, különc feltalálók, bajkeverők és mások, akiknek tehetségük van ahhoz, hogy alapvetổ kérdésekre választ találjanak. A kutatás második típusának társadalmi megbecsültsége ekkor emelkedni fog, mivel szorosan az új egyetemek oktatási miszsziójához fog kötődni. Amint az egyetemek elég vállalkozó szelleműek lesznek, a harmadik típusú kutatás szintén népszerúbbé fog válni, mivel felfedezik, hogy bevételre tehetnek szert, ha $\mathrm{K}+\mathrm{F}$ programjaikkal vállalatokat segítenek, és az ilyen kutatások a hallgatókat is vonzzák.

Az egyetemi kutatás átrendeződik, szélesebb körűvé válik és gazdagodik, de nem szúnik meg. A kutatás eszméje túl mélyen gyökerezik az egyetemek szellemiségében.

\section{Az új egyetem}

Jóllehet egyetemeink alapjait kétségtelenül az információtechnológia, a hálózatok és a digitális média alkotják, a piaci mozgásokra és a politikai folyamatokra szintén figyelemmel kell lennünk. Erre azért van szükség, hogy a piac és a politika változásaira reagálni tudjunk. Éppen ez utóbbi hatások azok, amelyek a legerôsebb nyomást fejtik ki ránk. Meg kell tehát vizsgálnunk ezeket az erôket és be kell mutatnunk, hogy milyen nagyszerû lehetôségek állnak azok elốtt az egyetemek előtt, amelyek ezekre reagálnak.

Az egyetemi oktatás az igények alapján át fog alakulni. Egyrészt a hallgatók elvárásai szerint, akik a tanulásba való befektetésük megtérülését várják; másrészt az üzleti szféra vezetői által megfogalmazott követelmények szerint, akiknek gyakorlati szaktudással rendelkező diplomásokra van szükségük; és végül a politikusok elvárásai nyomán, akik az állami támogatás fejében hatásosabb és hatékonyabb oktatást köve- 
telnek. Ezenkívül változások következnek be azért is, mert az egyetemeknek az új technológiákkal és a magáncégekkel kell versengeniük. A hagyományos lineáris oktatás szabad utat fog adni a „hipertanulási” környezetnek. A szakmai tanfolyamok lebonyolítása és különféle oklevelek kiadása a magasabbszintû oktatás új és jövedelmező ágává fog válni. A tananyag át fog szerveződni annak érdekében, hogy elősegítse a tudás és az információ közötti különbség megértését. Meg fog jelenni egy új típusú tanár, aki tanulóit jól tudja ösztönözni, kezelni és felkészíteni, s akinek a munkáját a tanulók teljesítményén mérik le.

Az egyetemi kutatás az új társadalmi szerződésnek megfelelően fog átalakulni: nagyobb hangsúlyt kapnak azok a kutatások, amelyek szaktudást (kompetenciát) és a cégekkel való együttmúködést eredményeznek. (Meg kell jegyeznünk, hogy az utóbbit az is elő fogja segíteni, hogy az ipari szektor leépíti saját kutatásait.) A kutatásokat egyre kevésbé állami forrásokból, s egyre inkább az egyetemek saját vállalkozásaiból fogják finanszírozni.

Manapság az egyetemeknek a társadalom visszás kérdéseivel, köztük például a kisebbségi esélyegyenlőségnek, egyes csoportok megkülönböztetett kezelésének, a nemek esélyegyenlőségének és a személyi szabadságjogok védelmének, a szólásszabadságnak és a politikai korrektségnek a kérdéseivel is meg kell birkózniuk. Azt egyelőre még nem lehet tudni, hogy ezek hogyan fognak alakulni. Az eredmény azonban semmi esetre sem fogja megakadályozni az új egyetem kialakulását, mert azok a kényszerek, amelyek ezeket a vitákat hajtják, nem annyira erôsek, mint azok, amelyek annak a megváltoztatását követelik, hogy mit és hogyan tanulunk, oktatunk és kutatunk.

Azok, akik válaszolnak a kihívásra, gazdagabb oktatási programokat, szakmailag hozzáértőbb diplomásokat, elégedett alkalmazottakat, szélesebbkörû kutatási lehetőségeket, szakmai továbbképzést és új oktatási gyakorlatot nyernek. Az oktatás előtt csakugyan fényes jövó áll.

Magyar Dóra fordítása

\section{Ajánlott irodalom}

„Az iskola alkonya” címú könyvében (School's Out, Avon Books, 1992) Lewis Perelman részletesen taglalja a jövô oktatásáról alkotott elképzelését, azt a paradigmát, amit „hipertanulásnak” nevez. Ezt a könyvet feltétlenül el kell olvasniuk. Ha azonban kedvelik az egyetemi hagyományokat, valószínúleg mélyen fel fogja háborítani önöket. Perelman magyarázatát a tudásról és a tanulásról vallott filozófiájáról egy vele készített interjúban olvashatják a Journal of Bionomics címú on-line folyóiratban (http://www.bionomics.org). 
„Értékvándorlás”című művében (Value Migration, Harvard Business School Press, 1995) Adrian Slywotzky hosszasan fejtegeti az „üzleti struktúra” koncepcióját. Példákat mutat be arra, hogy a fogyasztók hogyan pártolnak át a nagyobb értékeket nyújtó cégekhez.

„A poszt-kapitalista társadalom” címú munkájában (Post-capitalist Society, Harper Business, 1993) Peter Drucker a tanításnak és a tanulásnak az értelmiségiekre gyakorolt hatásait fejtegeti. Ez tulajdonképpen nem más, mint „Az új valóságok” címú múvében (The New Realities, Harper \& Row, 1989) kifejtett elképzelés továbbfejlesztése. Drucker gyakran azzal teszi múveit bonyolultságuk ellenére is könnyen érthetôvé és humoros olvasmánnyá, hogy kiválóan rámutat az állandóan munkálkodó történelmi erőkre és azok következményeire.

„A tudomány mứködés közben” címú könyvében (Science in Action, Harvard University Press) Bruno Latour - annak érdekében, hogy bemutassa, miként szülhet a kakofónia, az ellentmondás és a káosz tudományos igazságot - megkülönbözteti az „előgyártott tudományt” és a „múködő tudományt”.

„A multidiszciplináris gondolkodás elméleti alapjai” címû́ munkájában (Conceptual Foundation for Multidisciplinary Thinking, Stanford University Press, 1995) Stephen Jay Kline bemutatja, hogy az innováció folyamatai közel sem lineárisak, hanem számos visszacsatolást tartalmaznak. A szerzố kétségbe vonja, hogy a legtöbb innováció a kutatók agyában megszületố gondolattal kezdốdik.

Andy Grove a „Csak a paranoidok élik túl” (Only the Paranoid Survive, 1996) címú írásában arról számol be, hogy hogyan vezette az Intelt, és bemutatja a kutatás és az innováció folyamatait egy sikeres high-tech vállalatnál.

Charles Sykes „A professzorok átvilágítása” (ProfScan, St Martin’s Press, 1998) című könyvének megjelenése óta számos sikerkönyv született a felsőoktatás rákfenéirôl és korruptságáról. Még ha nem is értünk egyet ezeknek a könyveknek a megállapításaival, el kell ismernünk, hogy nagy sikerük volt, és emberek ezrei költöttek 24,95 dollárt rájuk. Ha mást nem is, legalább bepillantást nyújtottak az egyetemek gazdasági stratégiai problémáiba.

Az egyetemi kutatásokat csak ritkán értékelő Economist című folyóirat 1996 augusztus 24-én azt írja, hogy a „publikálj vagy pusztulj” szindróma csökkenti az oktatás értékét, mert elvonja az energiákat az oktatástól. Az egyetemek teljesítménye a legtöbb szempontból középszerú.

Eli Noam a Science című folyóirat 1995 októberi számának egyik kommentárjában, majd késóbb az Educom Review 1996 május-júniusi számában közölte az egyetemek lelepleződésérôl vallott nézeteit. Noam elsôsorban arról ír, hogy az információs technológia miként ássa alá az egyetemek hagyományos koncepcióját.

Eliott Soloway „A kulcs a tanár” (Teachers are the key, Communications for the ACM, 1996. júni-

us) címú munkájában ismételten leírja, hogy mennyire szükséges a tanítás és a tanárok hatékony fejlődése.

Andy Whinston és két munkatársa „A tanulás elektronikus piaca: közvetítés az oktatásban és az Internet" címû múvükben (Communications for the ACM, 1996 június) az oktatásban előforduló közvetítôi szolgáltatásokról írnak. 
A szerzố több cikket írt a fenti témákról, amelyeket a Communications for the ACM hasábjain olvashatnak: (1) „Az új mérnök képzése” (Educating a New Engineer, 1992 december); (2) „Új elvek megalkotása a kutatás fenntartására egyetemeinken” (Designing New Principles to Sustain Research in Our Universities, 1993 június); (3) „A jövố kihívásai az egyetemek számára” (The University’s New Challenges, 1996 május). Megjelent továbbá: „Az új egyetem üzleti stratégiája" (Business Design for the New University, Educom Review, 1996 november).

Az Új Mérnökök Központjában (Center for The New Engineer, CNE, http://cne.gmu.edu) Daniel Meanscé-vel közösen létrehoztuk a „hipertanulási” környezet egy prototípusát. A CNE tanulási modulok és virtuális munkahelyek tárházát tartja fenn; a matematikai és statisztikai frissítô modulok szintfelmérô és vizsgáztató tesztmodulok prototípusait tartalmazzák. 